\title{
YOUNG WOMEN'S REPRODUCTIVE HEALTH (ETHNOGRAPHIC STUDY ON YOUNG WOMEN'S KNOWLEDGE AND BEHAVIOR RELATED TO REPRODUCTIVE HEALTH IN BANTAN VILLAGE SLUMS MEDAN TEMBUNG)
}

\author{
Febri Siahaan and Aida Fitria Harahap \\ Universitas Sumatera Utara, Indonesia \\ aida@gmail.com
}

\begin{abstract}
Keywords: Reproductive Health, Knowledge, Behavior, Young Women
Abstract: $\quad$ This study discusses how the knowledge and behavior of young women in slums are related to reproductive health. The purpose of this study is to describe the knowledge and behavior of young women in slums. Whether the influence of slum environments with adolescent social behavior, how parents play in providing reproductive health education to their daughters, and how the rules exist in society limit young women's sexual behavior. The research method used in i research is a qualitative approach. The data collection techniques used are interviews and observations to the public. The result of the study is that reproductive health is understood as a matter of how to maintain the cleanliness of reproductive organs to avoid disease. The scope of the conversation also concerns sexual intercourse conducted by men and women. Parents usually provide knowledge of this only in the form of straightforward advice. Meanwhile, the local community also imposes moral sanctions in the form of censure, innuendo for deviant young women.
\end{abstract}

\section{INTRODUCTION}

This study examines the knowledge and behavior of young women related to reproductive health in slums. Slums are one of the problems of many problems caused by the increasing rate of urbanization. A limited environmental condition that can be seen from low occupancy conditions, limited facilities and low social, economic, and educational living conditions can affect the health of reproducing.

These conditions can found in residents living on the outskirts of the railway in Gang Dostahi Neighborhood Bantan sub-district of Medan Tembung Kota Medan.

Many houses are small and usually consist of only one bedroom, one living room, and one bathroom. The state of the environment around the settlement also looks narrow, dense and crammed. The livestock cages of the inhabitants are also many that are directly in contact with their homes. Rubbish was strewn everywhere, so it looked dirty. Air circulation and lighting conditions in the house are also weak. The average resident's home in this area has begun to become classified into a semipermanent house. These houses lined the railway line and formed a slum.

Rough occupancy conditions allow residents living in slums to be prone to deviant behaviors such as committing criminal acts, sexual harassment and moral deterioration in their communities. In general, the most vulnerable people with these living conditions are teenagers (in Indonesia, the age limit for teenagers is 11-24 years). Residential areas with slum conditions and densely populated areas tend to make uncomfortable. Unwitting behavior like this allows teenagers to do something that deviates from the norms that exist in society (Sadri, 2009).

The existence of those who lack the attention of the community in their environment makes them tend to realize themselves into a form of deviant behavior as a form of psychiatric expression in order to get the attention of the community. From a psychological perspective, it explains that basically adolescence is indeed a wrong time because it is at this time that a person experiences a transition or transition from the life of the children to the maturity that is often marked by personality crises. Very rapid 
physical and psychic changes cause internal anxieties, such as role changes, distress, the urge for freedom, social shock, prominent curiosity, excessive fantasy, strong group bonding, and identity crisis (Kartono, 1998).

Various deviant behaviors that young women who experience these living conditions may experience by performing the act of escaping from the house in search of pleasure themselves, having sexual intercourse with many unauthorized men or women.

The majority of people in xii neighborhood precisely in Gang Dostahi Bantan Village have search eyes as housekeepers, drivers, building workers, collectors of secondhand goods, scavengers, and even some who are unemployed. To get daily needs, parents have to work hard every day. Indirectly, the frequency of being with the child and communication that is intertwined becomes less that causes the child to grow and develop without adequate education from their parents, namely education for young women about reproductive health. The essence of reproductive health issues lies in a complex social context because reproductive health is influenced and affects social and economic life and is closely related to values, ethics, religion, and culture (Wagner, 1997).

Talking about reproductive health means talking about human resources. A good and correct understanding of reproductive health to adolescents, especially women, will have a positive impact that is wiser and more responsible for them. Also, with a good knowledge of reproductive health, women have sufficient insight to decide the things that concern the health of their reproductive life-for example, problems regarding pregnancy and early sex. A straightforward example is that by not abusing their reproductive organs so that they, especially young women, can avoid prenuptial sex and not experience the effects of such actions such as contracting STDs (Sexually Transmitted Diseases) or contracting the HIV.

Youth is an asset of human resources and is the backbone of future generations. Viewed from the composition of the population based on age group, the number of adolescents is the largest group. The supply of knowledge early on related to reproductive health will ultimately produce useful human resources, considering that in recent years, many cases of reproductive health and the impacts have been caused.

Knowledge of reproductive health tends to be ruled out in the process of maturity in adolescence. Also, knowledge of reproductive health is not worth talking about to adolescents even considered dangerous if the adolescent knows it. People, especially parents, still feel dating or reluctant, not even understanding the right way to discuss biological, psychological, and reproductive health issues with their child. Parents are worried that talking about sex will trigger their children to do things that are considered taboo.

Parents in these slums generally have a low educational background. So parents only provide explanations about things related to reproductive health using simple language. Not answer the teenager's questions about the changes that have occurred to him. So teenagers will only feel confused and tend to seek answers from other sources.

One of the most popular sources of teens that is most accessible is the internet. One result of this technological advancement is that there is much global information coming from different parts of the world. Unfiltered global information primarily related to reproductive health contributes to adolescent behavior patterns, such as giving adolescents a false understanding, especially concerning reproductive health. A young man experiencing turmoil due to changes that occur to him has no experience and tends to be overcome by the desire to try new things or has never experienced it. Adolescents will more easily adapt to unhealthy habits such as free sex, smoking, alcoholic beverages, and drug abuse and illicit injections.

According to the State Department in 2001, high-risk sexual behavior habits include having sex at a young age and contributing negatively to young women, especially to their newly developed reproductive organs. It is seen from about 70,000 young women less than 18 years old involved in sex industry prostitution found in 23 provinces. One of the sex industry continues to develop as in Yogyakarta, with famous prostitution areas such as Pasar Kembang in Malioboro area.

To understand reproductive health, we can see through his sexual behavior. Aktifitas sex and sexual behavior are two different things. According to Master and Johnson in Nugraha (1995) said sex activities include kissing, masturbation, and sex; this is undoubtedly related to each other. Meanwhile, sex behavior includes "visiting" or "dating" or being attracted to each other. However, the wrong sex behavior will lead to illegal sex activities as well, of course.

Slum conditions and social environments that are less considered by the community, tend to make the local community less concerned with norms, 
especially in limiting youth association. Teenagers living in slums tend to be closer to their peers, and even that closeness is a top priority that can replace their closeness to their families. Parents spend more of their time at work. The youth share each other's experiences. The lack of control of the family and the community about this issue led to the teenager getting the wrong information. Curiosity or curiosity makes them more likely to perform and have prenuptial sex themselves.

A society's sexual behavior is not only influenced by hormonal stimuli but the mind. The mind itself is influenced by experience, education and culture-E.g. in a society that has a relatively high infant mortality rate. Fertile women are valued more than the less fertile, and hence the myth of "many children have many fortunes." Alice Gibbons revealed about the Damal people in Irian Jaya (Gibbons in Kartono, 1998).

In traditional societies such as the Damal, sexual behavior is directed at printing as many children as possible to compensate those who die in war, hunger or disease. In addition, this was done to improve men's status, symbolizing the strength of the Damal tribe.

Modern human sexual behavior may be close to Sigmund Freud's concept of human sexuality. Human sexuality is not just a genitalia activity with procreative purposes, but rather a pleasure-seeking behavior in a broader sense (or eros) consisting of two elements: self-preservation and reproduction. (Kartono, 1998).

Although the motivation itself is biological, a person's sexual behavior pattern will be heavily influenced by different values and customs according to their religion, ethnicity, and socioeconomic status. A person's sexual behavior is influenced by where they grew up, how one brings himself into society and follows the rules and culture that exist. The above is what makes the author interested in examining how adolescents' knowledge and behavior in slums is related to their reproductive health.

\section{RESEARCH METHODS}

This research is qualitative research with an ethnographic approach. The research observes the behaviors, habits, and way of life of subjects studied to understand what is happening and experienced by research subjects in their daily lives holistically. The results of that observation are poured in the form of words and language in one scientific context. They are using various techniques, such as participant observation, interview techniques, and literature studies. The qualitative approach considers that meaning is an integral part of a person's experience in his or her social life with others (Bungin, 2011).).

Researchers use an in-depth interview technique or in-depth interview using an interview guide (interview guidelines). Spradley (1997) said that this type of in-depth interview method is undoubtedly based on the principle that researchers learn from people instead of studying. Interviews are aimed at local youth, especially young women living in slums. Also, interviews are also aimed at parents as their core families who have an essential role in their daughter's parenting and development related to reproductive health.

Researchers use participation observation techniques that participate in the daily activities of young women in this area, such as living in their homes, staying together with their families and establishing family relationships with teenagers and their parents. At the same time, data literature is obtained from related research objects, both in books and articles originating from the internet. This research was conducted in Medan City precisely on Jl. Padang Gang Dostahi Lingkungan XII Kelurahan Bantan Medan Tembung District Medan City.

\section{RESULTS AND DISCUSSIONS \\ 1. Youth Knowledge in Slums Lk. XII Bantan Village related to Reproductive Health}

The knowledge of reproductive health that each adolescent has certainly varies that can be influenced by various factors, such as access to accurate information about reproductive health itself. In slums, many teenagers have knowledge of reproductive health. From the observation of Researchers, such as girls who have experienced menstruation first, will pay more attention to their cleanliness. According to the informant Sari (15 years) that she usually if coming months at home using DUK that can be washed many times, but if to school use sanitary pads. Based on information from his parents that wearing sanitary pads can make the role dry. While according to informant Debby (21 years), during menstruation usually she replaces softex 3 times a day because of the pain.

In general, information about their reproductive health is obtained from various sources, such as from the internet or ipa books. This ultimately makes them have a diverse understanding in response to the meaning of reproductive health. 
According to the Party informant (17 years), that thehealthof reproduction concerns the relationship between men and women. Male sperm cells meet female eggs in the female uterus then there is fertilization that results in the child. While according to informant Debby (21 years), that healthy means free from disease, whereas reproduction means things related to the tool of womanhood where reproductive health is how we maintain and care for intimate organs to be clean and free from diseases such as hives, scabies and other diseases.

From the interview above, some adolescents interpret reproductive health as an issue that concerns sexual activity between men and women and how to keep their reproductive organs clean and there are even some other teenagers who are about 12 to 15 years old have not understood even just heard the word reproductivehealth.

Young women in this area generally get advice on the limits of their associations after they experience their first period from the parents. But the advice is not enough to explain the changes in youth. Adolescents in this area, consider parents to lack in-depth knowledge of reproductive healthrelated issues. Like the informant Debby (21 years old) that his parents only forbadehim from dating now and mereka even rarely discusses the changes and reproductive development of his daughter.

$\mathrm{K}$ reproductive health not only covers physical health but reproductive health also includes healthypsychology or related to the mental or psychological of aperson. Reproductive health also includes socially cultural health meaning to be able to adjust and consider the surrounding social values (religion, culture, environment) related to reproductive issues. There are several factors that affect the health of the body as well as the reproductive health of women in gang dostahi area, based on research that researchers conducted, namely:

\section{Environmental Factors}

Most residents around the slums have activities as scavengers, breeds (pigs). In addition, in this settlement, the means to get clean water is also difficult, as the informant Debby (21 year), that the water in the area is light brown from the well and there is no PAM water. As for drinking usually buy refillable water.

\section{Teen Social Factors}

In this area, many are inhabited by teenagers aged 12 to 18 years. Generally teenagers in this area prefer to spend time with their peers compared to their own families. Adolescent association contributes to influencing their reproductive health, this is due to adolescents who, in their development, tend to be more comfortable telling peers everything theyexperience. Information obtained from friends' stories without screening for true or false information, plus sexual urges due to hormones developing in the body, ultimately leads adolescents who do not have this experience to early sexual behavior and may be wrong.

\section{Education Factors}

In this area young women are more likely to attend school than young men. Usually men prefer to travel or work thanschool. Thus the young women have many opportunities to gain knowledge from various educationalmeans. With education, women can have a more mature insight into what is right and what is not, especially when it comes to reproductive health.

\section{Economic Factors}

Economic factors also affect reproductivehealth. It is also seen in life in the Dostahi Alley area. Most adults and their daughters spend a long time working at home not only domestic work but additional work such as taking care of secondhanditems. In addition, they are alsopreoccupiedby outdoor work such as working in factories, laborers, or collecting secondhand goods from various locations that are far enough away from their homes just to meet the needs of daily living. With this kind of busyness, it will force them to lose a lot of time or have little time to take care of themselves especially in the matter of hygiene of the body and reproductive organs.

\section{Cultural Factors}

One of the cultural elements affecting adolescent behavior towards reproductive health is belief orbelief. In general, the inhabitants of gang dostahi are Christian. In Christian teachings there are also rules that limit human sexual behavior. There is $a$ 7th decree that says "donot commit adultery".". But the reality today, there have been many teenagers having sex at a relatively youngage. In addition, teenagers living in the dostahi alley area rarely participate in religious groups. This is because they are less interested in it.

\section{Adolescent Behavior on Health}

First, to the health of the body. According to informant Debby (21 years old), hidup healthyby eating nutritious foods without preservatives, drinking water 3 to 4 glasses daily, regular exercise, regular eating, bathing 2 times a day. But if environmental conditions are limited, they are likely to strive to live clean. For example, water conditions 
that are murky if used can cause skin diseases. They tend to anticipate it by using a filter tub.

Second, to reproductive health. Para juveniles in this area maintain the cleanliness of the body by bathing and using soap. Given the poor water condition, they are forced to use the water, to bathe and lock when defecating or urinating. With such circumstances it is very likely germs enter and cause hives, and blisters. Reproductive health is not only about maintaining the cleanliness of reproductive organs, but reproductive health also concerns the behavioral problems of adolescents with the opposite sex.

Para teenagers in this area, usually often gather with their peers using makeup and tight clothes and shorts most of whom want to meet their partner. Their activities during dating also vary, such as Dina (pseudonym) 3rd grade junior high school student who reveals her courtship activities such as chatting, handrails, kissing, even groping breasts.

1. The Role of Parents and Society in Maintaining Patterns of Adolescent Behavior in Dostahi Gang Settlements

First, parental roles. For those with economic limitations, they have to work hard to make ends meet every day. Bagi those who already have families, precisely parents who have an important role especially to seek fortune for the needs of life not only for themselves, but their children. This situation is seen in many families living in Gang Dostahi, such as the informantsaid ibu lamriah (43 years) that if the work of her daughter is kept by her father or brother at home. In addition, he also advises against getting along first with men, because they are already poor and if they get along wrong let alone reliable, because there has been a lot of negatif newseverywhere there is rape, pregnant tampa husband.

Then according to sari informant (15 years), Her mothers tends to talk about teenage friendships, often advise you not to date first, do not get in to the wrong relationship, if I do not consider the child, whatis, then he is lazy to tell about the relationship with the parents.. While according to the informant said malau's father himself still took time to pay attention to his daughter, namely anyone who lives in his house can not be free, if there is a male friend brought home, can go out and remember the time.

Second, the role of society. People tend to be less restricted when it comes to reproductive healthissues. According to informant Debby (21 years old), people in her area if anyone is dating in BP (behind the factory) tend to be indifferent and leave it alone. The public's concern about the courtship behavior of local teenagers is less noticed, the public is more interested in talking about the disgraces that occur in teenagers. But in the event of sexual abuse by teenagers, society also gives a resition to the perpetrator. For example, beatings, and other acts of violence against perpetrators. While if teenage girls deviate from existing norms, Society tends to give moral resicance in form, innuendo, ridicule and spread the negative news from themouths.

In addition, parents tend to teach their child not to be close to other neighbor's children for fear that their child will be affected or fall entangleed by their friends. They consider teenagers in their area of residence to be many who have gone wrong in their association with the opposite sex. According to the informant Ibu Rindu (30 years), that if she hears bad news about teenagers who are pregnant or gossiped by people in her village, then she will tell the story and advise her daughter not to get too close and exemplified like that. From such information parents often advise their daughters to be more careful in maintaining relationships with male friends. These advices are often linked to examples that occur in the area.

\section{REFERENCES}

Bungin, Burhan. 2011. Penelitian Kualitatif : komunikasi, ekonomi, kebijakan publik dan ilmu sosial lainnya, Edisi kedua, cetakan ke-5. Kencana. Jakarta.

Kartono, Kartini. 1998. Patologi Sosial 2, Kenakalan Remaja. PT. Raja Grafindo Persada. Jakarta.

Kartono, Mohammad. 1998. Kontradiksi Dalam Kesehatan Reproduksi. Pustaka Sinar Harapan. Jakarta.

Nugraha, Boyke. 1995. Problema Seks dan Cinta Remaja. Bumi Aksara. Jakarta.

Sadri, Jhoni. 2009. Tinjauan tentang Perilaku Menyimpang Remaja di Kelurahan Sari Rejo Kecamatan Medan Polonia. Skripsi (S-1) Tidak Diterbitkan. Medan: Fakultas Ilmu Sosial dan Ilmu Politik Program Studi Kesejahteraan Sosial Universitas Sumatera Utara.

Spradley, James P. 1997. Metode Etnografi. PT. Tiara Wacana. Yogyakarta.

Wagner. Lola, dkk. 1997. Seksualitas di Pulau Batam. Pustaka Sinar Harapan. Jakarta. 